\title{
Antitumor and Antiviral Activity of Colombian Medicinal Plant Extracts
}

\author{
LA Betancur-Galvis $/^{+}$, J Saez$^{*}, \mathrm{H}$ Granados*, A Salazar**, JE Ossa
}

\begin{abstract}
Laboratorio de Virología, Departamento de Microbiología y Parasitología, Facultad de Medicina *Departamento de Química **Departamento de Biología, Facultad de Ciencias Exactas y Naturales, Universidad de Antioquia, Apartado 1226, Medellín, Colombia
\end{abstract}

Extracts of nine species of plants traditionally used in Colombia for the treatment of a variety of diseases were tested in vitro for their potential antitumor (cytotoxicity) and antiherpetic activity. MTT (Tetrazolium blue) and Neutral Red colorimetric assays were used to evaluate the reduction of viability of cell cultures in presence and absence of the extracts. MTT was also used to evaluate the effects of the extracts on the lytic activity of herpes simplex virus type 2 (HSV-2). The 50\% cytotoxic concentration $\left(C C_{50}\right)$ and the $50 \%$ inhibitory concentration of the viral effect $\left(E C_{50}\right)$ for each extract were calculated by linear regression analysis. Extracts from Annona muricata, A. cherimolia and Rollinia membranacea, known for their cytotoxicity were used as positive controls. Likewise, acyclovir and heparin were used as positive controls of antiherpetic activity.

Methanolic extract from Annona sp. on HEp-2 cells presented a $\mathrm{CC}_{50}$ value at $72 \mathrm{hr}$ of $49.6 \times 10^{3} \mu \mathrm{g} /$ $\mathrm{ml}$. Neither of the other extracts examined showed a significant cytotoxicity. The aqueous extract from Beta vulgaris, the ethanol extract from Callisia grasilis and the methanol extract Annona sp. showed some antiherpetic activity with acceptable therapeutic indexes (the ratio of $C C_{50}$ to $E C_{50}$ ). These species are good candidates for further activity-monitored fractionation to identify active principles.

Key words: ethnobotany - medicinal plants - antiviral - herpes simplex virus - citotoxicity - colorimetric assay

Scientific strategies for the in vitro evaluation of natural products with biological activity have changed in the past few years. One recent development is the highly automated bioassay screening based on colorimetric methods that quantify the proliferation of cell cultures (Mosmann 1983, Denizot \& Lang 1986), these techniques which are considered quick and inexpensive for the evaluation of antitumor (Carmichael et al. 1987, Rubinstein et al. 1990) and antiviral activity (Weislow et al. 1989) of a large number of natural product extracts, have also easily permitted to guide the isolation and purification of their biologically active principles (Cordell 1995).

Interest in a large number of traditional natural products has increased (Kurokawa et al. 1993, Cordell 1995, Vlietinck et al. 1995, Taylor et al. 1996). It has been suggested that aqueous and ethanolic extracts from plants used in allopathic medicine are potential sources of antiviral and an-

\footnotetext{
This work received financial support from the University of Antioquia.

${ }^{+}$Corresponding author. Fax: +574.51.06062. E-mail: Liliana.Betancur@uv.es

Received 29 July 1998

Accepted 10 February 1999
}

titumor agents (Chung et al. 1995, Vlietinck et al. 1995). Furthermore, the selection of crude plant extracts for screening programs has the potential of being more successful in its initial steps than the screening of pure compounds isolated from natural products (Kusumoto et al. 1995, Cordell 1995).

Finally another new research strategy for the study of the biological activity of natural products, is the search of new biological activities of natural products that have just been studied (Cordell 1995). Therefore, one of the objectives of our work was to evaluate the antiherpectic activity of some species of Annonaceae. Acetogenins isolated from the Annonaceae have been evaluated for both their cytotoxic activity in multiple ovarian cancer cell lines and their antitumor effects in a murine ovarian teratocarcinoma model in vivo (Rupprecht et al. 1990, Holschneider et al. 1994). The cytotoxic potency found for some of these compounds may be explained by the capacity that they have for inhibiting NADH-ubiquinone reductase activity in mitochondria (Degli Esposti et al.1994, Zafra-Polo et al. 1996).

\section{MATERIALS AND METHODS}

Plant collection - Annona sp., was collected in the city of Montería in the department of Córdoba, Colombia, at a mean altitude of $20 \mathrm{~m}$; voucher 
specimen was deposited under the number 12650 at the herbarium of the Joaquin Antonio Uribe Botanical Garden in the city of Medellín. $R$. membranacea, and Aristolochia cordiflora, were collected in the Rio Claro canyon, in the town of San Luis, department of Antioquia, Colombia, at a mean altitude of $700 \mathrm{~m}$; voucher of the $R$. membranacea and A. cordiflora were deposited under the numbers 1106 and 3712, respectively, in the Gabriel Gutierrez Villegas Herbarium of the National University at Medellín (HNUM). A. cherimolia was collected in the town of San Cristobal, department of Antioquia at a mean altitude of $1700 \mathrm{~m}$. C. gracilis was collected in the Department of Valle, Colombia, at a mean altitude of $700 \mathrm{~m}$. A. cherimolia and and C. gracilis were deposited under the numbers 4561 and 17C35 in the HNUM. Crescentia cujete and Chenopodium ambrosioides were collected in the city of Medellín and were deposited under the numbers 121 and 33 in the HNUM. The species collected are listed in Table I, with their common names and folk medicinal uses.

Extract preparation - The material (100 g) was dried in an oven at a temperature of $40^{\circ} \mathrm{C}$. The plant material of the A. muricata, the A. cherimolia and the $C$. grasilis were percolated with ethanol. The seeds of the Annona sp., and leaf/stem of the A. cordiflora were percolated with methanol. Then, the different extracts were evaporated near dryness under reduced pressure and were stored at a temperature of $4^{\circ} \mathrm{C}$ protected from the light, until there were used in the different cytotoxic assays, no longer than two months. The plant parts used for the extraction process are described in Table II.

Cell culture and virus - Bovine kidney cells (MDBK cell line no. ATCC CCL22) and human larynx epidermoid carcinoma cells (HEp-2 cell line no. ATCC CCL23) were grown as a monolayer culture in Eagle minimum essential medium (MEM) supplemented with $10 \%$ fetal bovine serum (FBS), 100 units $/ \mathrm{ml}$ penicillin, $100 \mu \mathrm{g} / \mathrm{ml}$ streptomycin, $20 \mathrm{mg} / \mathrm{ml}$ glutamine, $0.14 \%$ $\mathrm{NaHCO}_{3}$ and, MEM non-essential aminoacid and vitamins solution. The culture were maintained at $37^{\circ} \mathrm{C}$ in a humidified $5 \% \mathrm{CO}_{2}$ atmosphere.

HSV-2 was obtained from Center for Diseases Control and Prevention, Atlanta, Georgia. USA. The virus stock was prepared from HSV-2-infected HEp-2 cell cultures. The infected cultures were then subjected to three cycles of freezing-thawing, and centrifuged at $2000 \mathrm{rpm}$ for $10 \mathrm{~min}$. The supernatant was collected, titrated and stored at $-170^{\circ} \mathrm{C}$ in $1 \mathrm{ml}$ alliquots.

Cytotoxicity assay - The dry crude extracts were redissolved in dimethyl sulfoxide (DMSO, Sigma), then diluted 1:100 in cell culture medium at $2.5 \%$ FBS before preparing serial half-log 10 dilution in a $100 \mathrm{mg} / \mathrm{ml}$ to $10^{-6} \mathrm{mg} / \mathrm{ml}$ range. Both for tetrazolium-dye (MTT) (Mosmann 1983, Niks \& Otto 1990) and Neutral Red (NR) cytotoxicity assays (Flick \& Gifford 1984), adherent cell monolayers (MDBK, HEp-2) in culture were trypsinized and washed with culture medium. The cells were plated at 15,000 cells/well in 96-well flat-bottomed plate. After a $24 \mathrm{hr}$ preincubation period, extract dilu-

TABLE I

List of plants, their common names and their medicinal use(s)

\begin{tabular}{|c|c|c|c|}
\hline Folk use & Vernacular name(s) & Folk use & Reference \\
\hline \multicolumn{4}{|l|}{ Anonnaceae } \\
\hline Annona cherimolia & Chirimoya, Chirimoyo & $\begin{array}{l}\text { Antiparasitic, dysentery, } \\
\text { antidiarrheal }\end{array}$ & Bories et al. 1991 \\
\hline Annona muricata & Guanabana & $\begin{array}{l}\text { Diarrhea, abortifacient, } \\
\text { lactagogue }\end{array}$ & Coee \& Anderson 1996 \\
\hline $\begin{array}{l}\text { Annona sp. } \\
\text { Rollinia menbranacea }\end{array}$ & Guanabanito & Eatable, fruit, juice & Saez \& Correa 1992 \\
\hline $\begin{array}{l}\text { Aristolochiaceae } \\
\text { Aristolochia cordiflora }\end{array}$ & Carímbulo, Curare & Wound wash & Garcia-Barriga 1974 \\
\hline $\begin{array}{l}\text { Bignoniaceae } \\
\text { Crescentia cujete }\end{array}$ & Totumo & Respiratory affections & Garcia-Barriga 1974 \\
\hline $\begin{array}{l}\text { Chenopodiaceae } \\
\text { Beta vulgaris }\end{array}$ & Remolacha & $\begin{array}{l}\text { Antiparasitic, laxative, } \\
\text { skin diseases }\end{array}$ & $\begin{array}{l}\text { Yoshikawa et al. 1995, } \\
1996\end{array}$ \\
\hline Chenopodium ambrosioides & Paico & $\begin{array}{l}\text { Colds, hemostatic, vermifuge, } \\
\text { anthelmintic }\end{array}$ & Filipoy 1994 \\
\hline $\begin{array}{l}\text { Commelinaceae } \\
\text { Callisia grasilis }\end{array}$ & Crespinillo & Used for warts & Garcia-Barriga 1974 \\
\hline
\end{tabular}


TABLE II

Cytotoxicity of plant extracts on MDBK cells expressed as $\mathrm{CC}_{50}$ values obtained in $24 \mathrm{hr}$ assays

\begin{tabular}{lllc}
\hline Family and species & $\begin{array}{l}\text { Plant part } \\
\text { tested }\end{array}$ & Extracts & $\begin{array}{l}\mathrm{CC}_{50}(\mu \mathrm{g} / \mathrm{ml}) \\
24 \mathrm{hr} \mathrm{Neutral} \mathrm{Red} \mathrm{assay}\end{array}$ \\
\hline Annona cherimolia & Leaf & Ethanolic & $41.7 \times 10^{-3}$ \\
Annona muricata & Leaf & Ethanolic & $20 \times 10^{-4}$ \\
& Seed & Ethanolic & $24 \times 10^{-5}$ \\
Annona sp. & Seed & Methanolic & $34.5 \times 10^{-3}$ \\
Rollinia menbranacea & Root & Hexane & $45 \times 10^{-2}$ \\
Aristolochia cordiflora & Leaf/stem & Methanolic & $25.6 \times 10^{-1}$ \\
Crescentia cujete & Fruit & Aqueous & 20.4 \\
Beta vulgaris & Fruit & Aqueous & $26.4 \times 10^{3}$ \\
Chenopodium ambrosioides & Leaf & Aqueous & 7.1 \\
Callisia gracilis & Stem & Ethanolic & $25 \times 10^{-2}$ \\
\hline
\end{tabular}

tions were added to the appropriate wells and the plates were incubated for 24,48 or $72 \mathrm{hr}$ at $37^{\circ} \mathrm{C}$ in a humidified incubator with $5 \% \mathrm{CO}_{2}$. Untreated cells were used as controls. By MTT technique, the supernatants were removed from all wells and $25 \mu \mathrm{l}$ of MTT (Sigma) $(2 \mathrm{mg} / \mathrm{ml})$ solution in phosphate buffered saline (PBS) was added to each well and the plates were incubated for $2 \mathrm{hr}$ at $37^{\circ} \mathrm{C}$. Then $125 \mu \mathrm{l}$ of DMSO was added to the wells to solubilize the MTT crystals. The plates were placed on a shaker for $15 \mathrm{~min}$ and absorbency was read at $492 \mathrm{~nm}$ on multiwell spectrophotometer (Titertek Uniskan). Similarly by NR technique, $50 \mu 1 /$ well solution containing $0.033 \% \mathrm{NR}(\mathrm{w} / \mathrm{v})$ in PBS was added. After incubation $1 \mathrm{hr}$ at $37^{\circ} \mathrm{C}$, dye containing medium was removed and the wells were washed twice with $150 \mu \mathrm{l} /$ well warmed PBS. The cells were then lysed with $125 \mu \mathrm{l}$ of a $50 \% \mathrm{v} / \mathrm{v}$ mixture of ethanol and 0.1M Monobasic Sodium Phosphate to solubilize the NR. The plates were gently rocked for $15 \mathrm{~min}$ and the absorbency in each wells was read $550 \mathrm{~nm}$. Control cells lysed with DMSO $2 \mathrm{hr}$ previous to evaluation of cellular viability by the MTT technique were used to blank the spectrophotometer.

The percentage of cytotoxicity was calculated as (A-B)/A x 100, where A is the mean optical density of untreated wells and $B$ is the optical density of wells with plant extracts.

Antiviral assays - To screen for antiviral activity, MDBK or HEp-2 cell monolayer were grown in 96 well microtiter plates. Dilutions of the extracts were added $2 \mathrm{hr}$ before the viral infection. Ten infectious dosis were added to each well and incubated at $37^{\circ} \mathrm{C}$ in a humidified $5 \% \mathrm{CO}_{2}$ atmosphere for a period of $72 \mathrm{hr}$. Controls consisted of untreated infected, treated noninfected and untreated noninfected cells. Furthermore all tests were compared with positive controls (acyclovir and he- parin) tested simultaneously under identical conditions. The cellular viability was evaluated by MTT technique.

Data analysis - The $50 \%$ cytotoxic concentration $\left(\mathrm{CC}_{50}\right)$ and the $50 \%$ inhibitor concentration of the viral effect $\left(\mathrm{EC}_{50}\right)$ for each extract were calculated from concentration-effect-curves after linear regression analysis. The therapeutic index or selective index is defined as $\mathrm{CC}_{50}$ over $\mathrm{EC}_{50}$ (Piñeros et al. 1992).

\section{RESULTS AND DISCUSSION}

New scientific strategies for the evaluation of natural products with biological activity require the implementation of large-scale screening programs. Our laboratory has adopted a microculture assay based on metabolic reduction of MTT to evaluate the cytotoxic effect as well as the antiviral activity of plant extracts on different cells. Tetrazolium salt is metabolically reduced by viable cells to yield a blue Formosan product measurable in a multiwell scanning spectrophotometer. This technique permitted to evaluate dose-dependent-effect, by linear regression analysis showing acceptable $\mathrm{R}^{2}$ values and correlation coefficients.

Tables II and III, shows concentration of extract to produce a reduction of viability of cell cultures of a $50 \%$ (50 cytotoxic concentration values $\mathrm{CC}_{50}$ ), as determined by NR and MTT asssays. The ethanol extract from Annona sp. on MDBK and HEp- 2 cells presented $\mathrm{CC}_{50}$ values of 34.5 and 55 $\mu \mathrm{g} / \mathrm{ml}$ at $24 \mathrm{hr}$ respectively, furthermore the value for the same extract on HEp-2 cells at $72 \mathrm{hr}$ was $49.6 \times 10^{-3} \mathrm{mg} / \mathrm{ml}$. The cytotoxic activity of the $A$. muricata, A. cherimolia and $R$. membranacea species has been extensively proven. From these species, Bis-tetrahydrofuran Acetogenins such as rolliniastatin- 1 and rolliniastatin- 2 have been isolated and identified, both are potent inhibitors of 
TABLE III

Cytotoxicity of plant extracts on HEp-2 cells expressed as $\mathrm{CC}_{50}$ values obtained in 24 and $72 \mathrm{hr}$ assays

\begin{tabular}{lll}
\hline Species & $\mathrm{CC}_{50}(\mu \mathrm{g} / \mathrm{ml})$ & $\mathrm{CC}_{50}(\mu \mathrm{g} / \mathrm{ml})^{a}$ \\
& $24 \mathrm{hr}$ MTT & 72 hr MTT \\
& assay & assay \\
\hline Annona sp. & 55 & $4.96 \times 10^{-2}$ \\
Callisia gracilis & 100 & 22 \\
Rollinia membranacea & 4.12 & $\mathrm{ND}$
\end{tabular}

$a: 50 \%$ cytotoxic concentration; ND: not determinated.

the NADH-ubiquinone reductase (Complex I) activity of mammalian mitochondria (Degli Esposti et al. 1994). The comparison of the $\mathrm{CC}_{50}$ values of the extracts of these species with the $\mathrm{CC}_{50}$ values of the methanolic extract from the Annona sp. allows us to conclude that this extract is a good candidate for further studies of activity-monitored fractionation to identify the active principles, which according to chemical structure studies performed (Degli Esposti et al. 1994, Zafra-Polo et al. 1996) may be similar to a Mono or Bis-tetrahydrofuran Acetogenin. Neither of the other extracts examined showed an important cytotoxicity.

Annona sp. extract also inhibited HSV-2 replication in HEp-2 cells. Comparing the $\mathrm{CE}_{50}$ and therapeutic indexes values (the ratios of $\mathrm{CC}_{50}$ to $\mathrm{CE}_{50}$ ) for Acyclovir and Heparin (Wiltink \& Janknegt 1991, Bean 1992, Clercq 1995, Herold et al. 1995), Table IV, compounds whose antiherpetic activity has been proven, with the values of the Annona sp. extract, we conclude that they have an acceptable antiviral activity. Similarly the aqueous extract from Beta vulgaris showed a good therapeutic index. These species are good candidates for further activity-monitored fractionation to identify active principles.

\section{ACKNOWLEDGMENTS}

To the personnel of the Virology Laboratory, specially to Gloria Mercedes Mejía-Londoño, for collaboration.

\section{REFERENCES}

Bean B 1992. Antiviral therapy: current concepts and practices. Clin Microbio Rev 5: 146-182.

Bories C, Loiseau P, Cortes D, Myint SH, Hocquemiller, Gayral P, Cavé A, Laurens A 1991. Antiparasitic activity of Annona cherimolia seeds. Planta Med 57: 434-436.

Carmichael J, DeGraff WG, Gazdar AF, Minna JD, Mitchell JB 1987. Evaluation of tetrazolium-based semiautomated colorimetric assay: assessment of chemosensitivity testing. Cancer Research 47: 936942.

Coee FG, Anderson GJ 1996. Ethnobotany of the garifuna of eastern Nicaragua. Econ Bot 50: 71-107.

Cordell GA 1995. Changing strategies in natural products chemistry. Phytochemistry 40: 1585-1612.

Chung TH, Kim JC, Kim MK, Choi SC, Kim SL, Chung JM, Lee IS, Kim SH, Hahn KS, Lee IP 1995. Investigation of korean plant extracts for potential phytotherapeutic agents against B-virus Hepatitis. Phytotherapy Research 9: 429-434.

Clercq E 1995. Antiviral therapy for human immunodeficiency virus infections. Clinl Microbiol Rev 8: 200239.

Degli Esposti M, Ghelli A, Ratta M, Cortés D, Estornell E 1994. Natural substances (acetogenins) from the family Annonaceae are powerful inhibitors of mitocondrial NADH dehydrogenase (complex I). Biochem J 301: 161-167.

Denizot F, Lang R 1986. Rapid colorimetric assay for cell grow and survival modifications to the tetrazolium dye procedure giving improved sensitivity and reliability. J Immunol Meth 89: 271-277.

Filipoy A 1994. Medicinal plants of the pilaga of central chaco. J Ethnopharmacol 44: 181-193.

Flick DA, Gifford GE 1984. Comparison of in vitro cell cytotoxic assays for tumor necrosis factor. J Immunol Meth 68: 167-175.

Garcia-Barriga H 1974. Flora Medicinal de Colombia, Botánica Médica, 2nd ed., Universidad Nacional de

TABLE IV

Cytotoxicity and Anti-HSV-1 activity of plant extracts on HEp-2 and MDBK cells expressed as $\mathrm{CC}_{50}$ and $\mathrm{EC}_{50}$ values obtained with MTT after of $72 \mathrm{hr}$ of incubation

\begin{tabular}{llllll}
\hline Species & $\begin{array}{l}\mathrm{EC}_{50(\mu \mathrm{g} / \mathrm{ml})} \\
\mathrm{MDBK}\end{array}$ & $\begin{array}{l}\mathrm{CC}_{50(\mu \mathrm{g} / \mathrm{ml})} \\
\mathrm{MDBK}\end{array}$ & $\begin{array}{l}\mathrm{EC}_{50(\mu \mathrm{g} / \mathrm{ml})} a \\
\mathrm{Hep}-2\end{array}$ & $\begin{array}{l}\mathrm{CC}_{50(\mu \mathrm{g} / \mathrm{ml})} b \\
\mathrm{HEp}-2\end{array}$ & $\begin{array}{l}\text { Therapeutic index } \\
\mathrm{CC}_{50} / \mathrm{EC}_{50}\end{array}$ \\
\hline Callisia grasilis & $\mathrm{NA}$ & 84 & 10.5 & 22.0 & $2.09^{c}$ \\
Annona sp. & $\mathrm{NA}$ & $4.06 \times 10^{-3}$ & $5.90 \times 10^{-3}$ & $4.96 \times 10^{-2}$ & $8.40^{c}$ \\
Beta vulgaris & 480 & $>26.43 \times 10^{6}$ & $\mathrm{NA}$ & $\mathrm{NC}$ & $>55.06 \times 10^{3 d}$ \\
Aciclovir & 2.88 & $9.12 \times 10^{4}$ & + & + & $31.6 \times 10^{3 d}$ \\
Heparin & 4.41 & $13.2 \times 10^{5}$ & + & + & $298.4 \times 10^{3 d}$
\end{tabular}

$a$ : $50 \%$ inhibitory concentration of the viral effect; NA: no activity; +: has activity but it was not determinated quantitatively; $b: 50 \%$ cytotoxic concentration ; NC: no cytotoxicity; $c$ : in relation to Hep-2; $d$ : in relation to MDBK. 
Colombia, Talleres editoriales de la imprenta nacional, Bogotá, DC 562 pp.

Herold BC, Gerber SI, Polonsky T, Belval BJ, Shaklee PN, Holme K 1995. Identification of structural features of heparin required for inhibition of herpes simplex virus type 1 binding. Virology 206: 1108-1116.

Holschneider CH, Johnson MT, Knox RM, Rezai A, Ryan WJ, Montz FJ 1994. Bullatacin in vivo and in vitro experience in an ovarian cancer model. Cancer Chemother Pharmacol 34: 166-170.

Kusumoto IT, Nakabayashi T, Kida H, Miyashiro H, Hattori M, Namba T, Shimotohno K 1995. Screening of various plant extracts used in ayurvedic medicine for inhibitory effects on human immunodeficiency virus type $1(\mathrm{HIV}-1)$ protease. Phytotherapy Research 9: 180-184.

Kurokawa M, Ochiai H, Nagasaka K, Neki M, Xu H, Kadota S, Sutardjo S, Matsumoto T, Namba T, Shiraki K 1993. Antiviral traditional medicines against herpes simplex virus (HSV-1), poliovirus, and measles virus in vitro and their therapeutic efficacies for HSV-1 infection in mice. Antiviral Research 22: 175-188.

Mosmann T 1983. Rapid colorimetric assay for cellular grow and survival: application to proliferation and cytotoxicity assays. J Immunol Meth 65: 55-63.

Niks M, Otto M 1990. Towards an optimized MTT assay. J Immunol Meth 130: 149-151.

Piñeros J, Garcia-Barriga H, Iregui A, Prias E, Perdomo C, Puerta HF 1992. Plantas Medicinales, Compendio de Farmacología Vegetal, 2da ed., Escuela de Medicina Juan N. Corpas, Fondo Editorial Universitario, Santa Fé de Bogotá, DC, 211 pp.

Rubinstein LV, Shoemake RH, Paull KD, Simon RM, Tosini S, Skehan P, Scudiero DA, Monks A, Boy MR 1990. Comparison of in vitro anticancer-drugscreening data generated with a tetrazolium assay versus a protein assay against a diverse panel human tumor cell lines. J Nat Cancer Institute 82: 11131118.
Rupprecht JK, Hui Y-H, McLaughlin JL 1990. Annonaceous acetogenins: a review. J Nat Prod 53: 237278.

Saez J, Correa C 1992. Acetogeninas en las Semillas de Rollinia membranacea, PhD Thesis, Facultad de Ciencias Exactas y Naturales, Universidad de Antioquia, Medellín-Colombia, 160 pp.

Taylor RSL, Manandhar NP, Hudson JB,Towers GHN 1996. Antiviral activities of nepalese medicinal plants. J Ethnopharmacol 52: 157-163.

Vlietinck AJ, Van Hoof L, Totté J, Lasure A, Vanden Berghe D, Rwangabo PC, Mvukiyumwami J 1995. Screening of hundred Rwandese medicinal plants for antimicrobial and antiviral properties. J Ethonopaharmacol 46: 31-47.

Weislow OW, Kiser R, Fine D, Bader J, Shoemaker RH, Boyd MR 1989. New soluble-formazan assay for HIV-1 cytopathic effects: application to high-flux screening of synthetic and natural products for AIDSantiviral activity. J National C Ins 81: 577-586.

Wiltink EHH, Janknegt R 1991. Antiviral drugs. Pharmaceutisch Weekblad Scientific ediction 13: 5868.

Yoshikawa M, Murakam T, Kadoya M, Matsuda H, Yamahara J, Muraoka O, Murakami N 1995. Betavulgarosides i, ii, iii, iv, and v, hypoglycemic glucuronide saponins from the roots and leaves of beta vulgaris 1 (sugar beet). Heterocycles 41: 16211626.

Yoshikawa M, Murakam T, Kadoya M, Matsuda H, Yamahara J, Muraoka O, Yamahara J, Murakami N 1996. Medicinal foodstuffs iii. sugar beet (1): hypoglycemic oleanolic acid oligoglycosides, betavulgarosides i, ii, iii, and iv, from the root of beta vulgaris 1 (chenopodiaceae). Chem Pharm Bull 44: 1212-1217.

Zafra-Polo MC, Gonzáles MC, Estornell E, Sahpaz S, Cortés D 1996. Acetogenins from Annonaceae, inhibitor of mitocondrial complex I. Phytochemistry 42: 253-271. 
Biological Activity of Colombian Plant - LA Betancur-Galvis et al. 